\title{
Unsettling Lessons: Teaching Indigenous Politics and Settler Colonialism in Political Science
}

Nancy D. Wadsworth, University of Denver

ABSTRACT Indigenous politics and history are central to and, indeed, intertwined with the history and politics of many if not most contemporary nations, yet the topics of indigenous politics and settler colonialism are rarely taught in undergraduate political science programs. This article outlines the pedagogical utility of an undergraduate course focused on indigenous history and politics, approached through a comparative race politics framework. The course on which this article is based compares state power and indigenous rights in the United States, Australia, and Latin America in historical context, but many variations are possible. The article first reviews the context for developing the course, the challenges related to teaching the subject, and my primary teaching objectives. It then outlines three pedagogical strategies applicable in other course frameworks and discusses positive learning outcomes I have observed as I refine this teaching area.

\begin{abstract}
- n 2012-2013, the Idle No More movement led by Canadian First Nations groups inspired a surge of street-level public activism and a vibrant, global social media presence. Movements of indigenous people confronting contemporary settler-colonial states constitute some of the most compelling political phenomena in the world today. ${ }^{1}$ Indigenous peoples' political engagement is anything but new: sovereignty, treaty rights, tribal autonomy, land, antiracism, and natural-resources preservation have long galvanized Native activism. However, with the help of modern communication technology, indigenous political efforts have become increasingly coordinated and global. Like prodemocracy movements in the Middle East and environmental movements around the planet, Native political movements are cross-national forces that challenge entrenched historical legacies, engage with local and international political bodies, and advocate on behalf of pressing policy concerns.

Yet, it is possible-if not inevitable-that the average political science undergraduate in the United States will never be exposed to more than fleeting references to Native Americans during a political science major, much less learn about indigenous people (in any geographical context) as living political agents and even critics of modern states. Stand-alone courses on indigenous politics are scarce, but even political science listings on racial and ethnic politics typically overlook Native groups to focus on more familiar domestic communities.
\end{abstract}

Nancy D. Wadsworth is associate professor of political science in the department of political science at the University of Denver, and she is the author of Ambivalent Miracles: Evangelicals and the Politics of Racial Healing (2014). She can be reached at Nancy. Wadsworth@du.edu.
There are a number of reasons for this. Certain predispositions in political science arguably "shield or distract scholars from seeing the value and importance of indigenous politics" and inhibit the study of settler colonialism in the discipline (Bruyneel, Forthcoming, 1). ${ }^{2}$ Historically, approaches to race in political science, at least in the United States (somewhat less so in Canada), attend much more to legacies of slavery and immigration dynamics than to the treatment of Native Americans (McClain and Garcia 1993). The paucity of course listings also reflects that, currently, there are probably fewer than 20 American professional political scientists focusing on indigenous politics. 3 So far, political scientists are underrepresented in the vibrant cross-disciplinary body of indigenous-politics scholarship in North America.

The "forgetting" of Native Americans within the American political science curriculum not only reifies Native peoples' marginalization on their own continent, it also perpetuates the dominant society's illiteracy regarding histories and ongoing political encounters. Yet, settler-indigenous interactions are foundational to and, indeed, constitutive of the political development of the United States and other nations sprung from settler colonialism. Inattention to historical and current dimensions of indigenous-settler politics weakens political science as an undergraduate field, forfeiting opportunities to more thoroughly explore subjects that are central to political science. These subjects include the following:

- the fundamental questions of democratic theory, such as how social-contract theory was conceived vis-á-vis the indigenous peoples that European settlers encountered (or imagined) and applied to justify dispossessing them of their land and life ways 
- the long-term development of collective narratives about and political negotiations of sovereignty, territoriality, jurisdiction, and citizenship

- the dynamics of federalism and the resulting relationships among nations, states, tribes, and other majority and minority communities

- the development of constitutional law in relation to settler entitlements and semiautonomous nations

- the origin(s) and spread of race as an epistemological and political category, operationalized in varying ways through myth, law, culture, and political institutions in different geographical contexts.

Embedded in these areas of inquiry is the paradox that liberal capitalist democracies-early modern Europeans' signal experiments in free societies-were constituted, in part, through the systematic subordination, removal, and subordination of Native populations, as were most nonliberal settler-colonial societies (e.g., encomienda and communist regimes in Latin America). The dearth of attention to indigenous and settler-colonial politics in the standard undergraduate political science curriculum contributes to the ongoing historical, political, cultural, and epistemological erasure of Native communities in North America.
I teach in an undergraduate political science department at a private university in the Rocky Mountain West, where-as in most US colleges-Native students (i.e., measured as American Indian or Alaska Native) represent less than $1 \%$ of the total traditional undergraduate body-or, at any given time, two to three dozen students of more than 5,300 (University of Denver 2012). A subset of our students tends to be active in the Native Student Alliance, especially with regard to a controversy over retaining a former mascot offensive to Native students. Students from the white-majority culture range from unaware of the presence of Native students in their midst, to uninterested or uninformed, to overtly hostile if Native perspectives challenge their perceived entitlements (e.g., access to a beloved mascot image). Because undergraduate classes on the politics of race rarely incorporate indigenous issues, North American students of color, white students, and international students alike tend to have little meaningful exposure to indigenous politics, cultures, or histories. This can be a delicate environment in which to address legacies of conquest, political subordination, resistance, and competing notions of sovereignty under settler colonialism. However, relative ignorance of the subject also can be beneficial because students' biases may be less fixed than they are relative to other race-related topics.

\section{Perhaps the greatest obstacle to exploring the reverberations of settler colonialism on indigenous communities is that it requires members of the settler-majority culture not only to view politics, knowledge systems, and history from the perspective of some of the most violated and marginalized communities on Earth, but also to recognize the politics of settler colonialism and indigenous resistance as ongoing rather than merely historical.}

In this article, I outline the pedagogical utility of an undergraduate course focused on indigenous history and politics, approached through a comparative race politics framework. The particular course on which this article is based compares state power and indigenous rights in the United States, Australia, and Latin America in historical context, but many variations are possible. This approach offers instruction in macropolitical developments (e.g., the imposition of Western epistemological and political paradigms across a populated planet) and microdynamics (e.g., localized examples of contestations over power and rights), with an ongoing analysis of how different European (and later multicultural) cultures asserted entitlements against Native peoples. I first present an overview of the context for developing the course, the challenges related to teaching the subject, and my primary teaching objectives. I then outline three pedagogical strategies applicable in other course frameworks and discuss positive learning outcomes that I have observed as I refine this teaching area.

\section{“UNSETTLING" SETTLER KNOWLEDGE}

I use an analytical approach that-although it is hoped to be of value to Native students-aims to be accessible to and especially instructive for a majority population that includes whites and nonNative students of color who descend from settlers in some way and who know little about indigenous political history. (Indigenous studies call this the "settler-majority" culture.) Understanding one's cultural-educational environment can help to customize an introductory course.
Because most American political science majors who have been exposed to race politics typically have done so through the frames of interest-group politics, voting behavior, and public opinionin which data on Native Americans are limited-students will be reasonably unsure where Indians fit as political agents. Indeed, this is a confusing empirical question but a fertile entry point for learning because indigenous politics challenge the very notion that Native communities must "fit" into or accommodate settler-colonial paradigms of membership and obedience. Courses on American political thought or constitutional law typically treat US-Indian relations intermittently, if at all. Moreover, most political science undergraduates have been trained through an educational optic that, if it identifies colonialism, tends to see Americans as colonists rather than colonizers and that defines racial "progress" as a process of integrating into the US political system, not as a critique of the system's governing assumptions. Indigenous communities tend to pose a distinct counterpoint to other forms of racial and ethnic politics, particularly in neoliberal societies. Perhaps the greatest obstacle to exploring the reverberations of settler colonialism on indigenous communities is that it requires members of the settlermajority culture not only to view politics, knowledge systems, and history from the perspective of some of the most violated and marginalized communities on Earth but also to recognize the politics of settler colonialism and indigenous resistance as ongoing rather than merely historical.

Given these challenges, I pursue five overarching objectives related to learning process and content. I aim to (1) create channels for 
identifying and disarming built-in defensiveness that members of the majority culture tend (often unconsciously) to bring to the subject; and (2) leverage student curiosity about Native Americans, which often is high, to cultivate investment in an analytical enterprise that raises inquiries about the role of academic knowledge with regard to indigenous politics. I ask students to (3) consider the impact of Western epistemological, methodological, and political paradigms from the perspectives of Native peoples. (4) I use topical "throughways"-that is, subjects that render visible the ways in which Western knowledge systems and political paradigms have been applied across different geographical contexts to institute power structures (often racialized) that politically constrain indigenous peoples. An example of a throughway is the almost identical use by different early Anglo settler-colonial polities of the notion of "jurisdiction" to circumscribe, discipline, and/or erase indigenous bodies while advancing settler claims. Finally, and throughout, (5) students are introduced to a transferable analytical skill set for identifying how political theories, state structures, and cultural and political institutions wield power to subjugate or validate political subjects, and how those subjects succumb, resist, or overcome. This skill set is applicable to other subjects in and beyond political science. The following three specific pedagogical strategies serve these five objectives.

\section{THE RACIAL POLITICS OF EPISTEMOLOGY}

Neither the European West's treatment of indigenous peoples nor indigenous people's resistance strategies across time can be understood without examining how Occidental knowledge systems constructed them as "other" through discourses of religion, civilization-savagery, and race. Introducing students early to the role of epistemological and disciplinary frameworks as instruments in the political project of European colonial expansion builds analytical depth into the learning experience. This strategy especially addresses objectives (2) and (3) listed previously.

I introduce the concept of "unsettling" to cultivate a disposition for approaching unfamiliar conceptual "territory." 4 (Territory is a key term in the study of indigenous politics that students will learn to use with increasing self-awareness.) Unsettling, as I apply it, denotes the idea that most members of settler societies have been socialized into a worldview constituted through a colonialist lens, such that we tend to take for granted concepts including "the nation-state" as a political unit and "sovereignty" or "citizenship" as benefits delivered and protected through the state. Native communities have been positioned very differently vis-á-vis such concepts. To honestly investigate the modern political experiences of indigenous communities impacted by settler colonialism, then, we first must be willing to "unsettle" our unconscious orientations to concepts such as time, space, property, law, and membershipall of which European settlers leveraged to justify the conquest, control, and cordoning off of Native populations, even while they promoted egalitarian political structures for themselves and their descendants. Stated differently, liberal democratic institutions and principles did not just incidentally entail but rather required colonial viewpoints; otherwise, the differential treatment of Native peoples was rationally unjustifiable. 5 Untangling that paradox of "consentbased" democratic governance contingent on the demolition of another culture lies at the heart of any study of settler colonialism and indigenous politics in the modern era.

An especially unsettling experience for many students is discovering race itself to be not a fixed biological or cultural reality but rather an idea set that humans invented in historical time and geopolitical context. As Rogers Smith and others have pointed out, "race" is not simply an independent variable-an essential identity reflected, expressed, or enacted in political life-as behaviorist political science tends to treat it. Rather, "race" is an outcome, a set of identity categories produced and transformed over time through knowledge discourses, elite political actors, institutions, and the state itself (Smith 2004, 45).

Historian George M. Fredrickson's concise Racism: A Short History (2002) provides a useful introduction to the origins and development of modern racism. As he defines it, modern racism is characterized primarily by two phenomena: (1) the notion of designated groups' "indelible" inferiority, and (2) the erection by societies of a thoroughgoing racial order to enforce racial hierarchy. Fredrickson provides useful instruction on the profound social constructedness of race and racism, tracing modern racism's rise in early Spanish anti-Semitism in the sixteenth century through the systems of German Nazism, American Jim Crow, and South African Apartheid.

However, this work also provides a provocative puzzle in the context of modern settler states: Fredrickson interprets the treatment of Native peoples under settler colonialism as existing outside the boundaries of the modern racist orders that he identifies. First, he argues, Europeans never systematically applied a purity-of-blood doctrine against indigenous peoples in the New World in the way that this doctrine was applied against Jews and people of African ancestry in other cases. Second, compared to other modern racial orders, mixing between Natives and Europeans in colonial contexts enabled relative mobility of racial status. Frederickson thus reads treatment of indigenous peoples under settler colonialism as examples of exploitation but neither fully racialized nor fully modern racist systems (2002, 35-41). This interpretation oddly-or perhaps necessarily-seems to exempt settler colonialism from the category of a modern racist system by rendering it somehow prior to or outside rather than emblematic of and concurrent with the other examples he describes. This paradox of exclusion provides an opportunity for students to puzzle through the defensibility of a scholar's typology. Why, we ask, might Fredrickson defend the peripheralization, as it were, of Native peoples' experiences under settler colonialism? I use a midterm essay assignment to allow students to plumb this topic.

From a Native perspective, aboriginal experiences under colonialism are foundational-not peripheral-to understanding the histories, functions, and effects of racism. Native scholars spell this out with a clarity that, again, is unsettling but invariably illuminating for students. Linda Tuhiwai Smith's reflections on the role of methodology in the study of indigenous peoples in Decolonizing Methodologies renders more visible the epistemological power structures that grounded European settler colonialism, including discourses that it produced to authorize its advancement (Smith 2007). Smith interrogates four terms-imperialism, history, writing, and theory-that constitute "problematic" words from an indigenous perspective but that illuminate how "indigenous languages, knowledges and cultures have been silenced or misrepresented, ridiculed or condemned in academic and popular discourses" $(2007,20)$. In so doing, she unmasks conceits of knowledge objectivity built into Western research paradigms, revealing how-when applied to Native peoples-Eurocentric "knowledges" were always driven by ideology and power. As a major means through which Enlightenment Europe constitutes its identity, scientific research has been indispensable to colonialism and imperialism. Indeed, the counting and categorizing activities of empiricism (itself a Eurocentric enterprise) often perpetuated erasure, misinformation, and violence toward Native peoples. 
Therefore, research by and for indigenous peoples is a fraught enterprise but also can be a means of resistance and self-determination through what Smith calls "researching-back," through more Nativecentric or at least historically balanced approaches (Smith, 2007). ${ }^{6}$

To render some of Smith's claims more concrete for undergraduates disoriented by the unfamiliar experience of critiquing the methods of scientific rationalism, I use "Bones of Contention," a BBC documentary that examines tensions between scientists and Native American tribes under the Native American Graves Protection and Repatriation Act (Peck and Seaborne 1998). In 1868, by order of the Surgeon General, the US Army collected the remains of Native Americans under the auspices of-among other reasons-studying the intelligence levels of different races. When the Smithsonian Institute inventoried this collection in 1985 , the remains of more than 18 ,ooo people were identified. Here, we learn, archaeology served as an arm of a political and ideological enterprise, authorized to turn even Native biological remains into scientific and government property, without consent from descendants. Many contemporary Native Americans see these practices as continuing violations of the dead and a spiritual affront. The documentary reviews efforts to create more collaborative solutions to understanding the past while also respecting the cultural values of the living descendants of these objects of scientific interest.

\section{THE OPERATIONALIZATION OF CONQUEST}

Consideration of how particular knowledge paradigms had an impact on indigenous peoples' experiences under settler colonialism provides a basis for examining how ideas are executed through political structures in particular contexts. My second pedagogical strategy examines the relationship between elite-level policies toward Natives-which are always undergirded by knowledge claims that justify action-and the practices of ordinary settler citizens and institutions on the ground. In particular, ideas regarding contract and sovereignty, which are deeply linked to concepts of time and space, propelled the development of power structures under settler colonialism that continue to inform the political challenges Native communities face. contract (which depended on the idea of terra nullius to justify conquest without complete consent), settlers used the right of husbandry, on the one hand, and the notion that Native peoples lacked sovereignty, on the other, to theoretically trump Native rights and simultaneously construct settler-colonialist ideas of properly political government $(2007,53-4)$. This is only one of the logics that periodically justified the violation of treaty rights when it served the settler nation.

It is meaningful for students to recognize how the settler contract was not just a heuristic device but rather a package of ideas planted in historical time as settlers "carr[ied] law with them" to create the modern world (Pateman and Mills 2007, 55). Analyzing this use of law drives home the reality that settler-colonialism's devastation of Native tribes co-constitutes modern legal structures rather than being an aberration or unintended side effect of them. One of the logics of the modern state is that "any recognition of Native nations must be on the terms of the new imperium, [because] inside the territory of the modern state there can be only one sovereign power" (2007, 59). Pateman and Mills' work contextualizes the political challenges currently facing indigenous people by interrogating the legitimacy of democratic states "whose 'beginning' is the settler contract." Their work prompts us to ask what it would mean to build a "new settlement with Native peoples," one not based on colonialism $(2007,77)$.

Work by historian Lisa Ford adds further historical background to Pateman and Mills' insights. In Settler Sovereignty (2010), Ford uses archival material to compare how the "legal trinity of nation statehood-sovereignty, jurisdiction, and territory"-developed in New South Wales (Australia) and the United States between 1788 and 1835 . Using court records, letters, and other primary sources, Ford found that the shared everyday practices among indigenous peoples, ordinary European settlers, local political elites, and federal authorities shaped legal notions of jurisdiction, often very messily. Despite similar notions of settler contract in the two geographical contexts, sovereignty was not an easy idea to execute in real time; indeed, it was highly fluid and contested for decades as distinct societies negotiated jurisdiction over settler and Native crimes. Norms of reciprocity, retaliation, and diplomacy on both sides of the settlement line kept questions of jurisdiction relatively open for years.

\section{Despite similar notions of settler contract in the two geographical contexts, sovereignty was not an easy idea to execute in real time; indeed, it was highly fluid and contested for decades as distinct societies negotiated jurisdiction over settler and Native crimes. Norms of reciprocity, retaliation, and diplomacy on both sides of the settlement line kept questions of jurisdiction relatively open for years.}

Carole Pateman and Charles Mills' interrogation of what they call "the settler contract" within social-contract theory provides a powerful segue from epistemology to policy on the ground (Pateman and Mills 2007). The settler contract is "a specific form of the expropriation contract and refers to the dispossession of, and rule over, Native inhabitants by British settlers in the two New Worlds" (2007, 38). Pateman traces how the settler contract was invoked in political theory and the law of nations in the seventeenth and eighteenth centuries to justify occupation of Native lands by British colonizers, albeit through different logics in Australia and the United States (36). Drawing on Grotius's rendering of terra nullius and Locke's social
Not until settler-colonialist legal structures achieved conflation of sovereignty, territory, and jurisdiction under federal apparatuseswith the help of developing notions of race and racial inferioritydid "perfect settler sovereignty" develop to justify the removal of indigenous peoples and legally destroy previously recognized indigenous rights (Ford 2010, 2). Ford's scholarship introduces students to archival methods and illuminates the varied and fluid ways in which political power can be executed-from trader-to-chief negotiations on Native trails, to settler juries deciding the outcome of local crimes, to devastating relocation decisions made by courts in Sydney and Washington, DC. 
Building on Ford's work, I use political scientist Kevin Bruyneel's The Third Space of Sovereignty (2007) to explore the development of American settler colonialism into the twenty-first century. His volume deciphers indigenous-US settler politics between the Civil War and the present as a conflict over spatial and temporal boundaries, in which indigenous claims often are seen as somehow "out of time" or not modern and on the edges of politically recognized space (Bruyneel 2007, xiii-xv). What Bruyneel calls "colonial ambivalence" over the scope and location of tribal sovereignty and Native peoples' relationship to the neoliberal state produces a national uneasiness toward indigenous sovereignty and rights that continues to replay in legal, policy, and public discourse about Native Americans. However, because colonization is never fully complete and the colonized are never entirely without agency, indigenous resistance tends to happen in a political "third space" through which Native activists attempt to politically exploit the "inconsistencies, contingencies, and fissures in the practices of colonization and decolonization" (Bruyneel 2007, xviii).

Pedagogically, Bruyneel's framework illuminates how contemporary political strategies of indigenous peoples-for example, around rights to gaming revenues or land acquisition-are commonly constrained by centuries-old impositions of state power that defined Natives as alternately situated inside and/or outside of a colonialist political system. In the US case, state power was imposed through treaty making; war; church-state missionary partnerships; removal; federal policy that redefined tribes' relationship to land, family relationships, and community; creation of the Bureau of Indian Affairs; and the late, unilateral extension of citizenship in 1924-all of which influence how and where indigenous groups pitch their political battles today. Bruyneel's research draws attention to the deeply contingent, socially constructed nature of claims to sovereigntya reality that indigenous politics probably reveals better than few other cases can. The third-space framework also illuminates how indigenous groups today approach political engagement in other geographical contexts in which-despite the political form of the state they are in-they are often situated not quite inside but not quite sovereign. examples of how ideas about race, civilization, sovereignty, and democracy were used politically in two "New World" contexts on the bodies of indigenous peoples, students are in a position to sharpen their growing comparative skills. Various texts serve this purpose but, most recently, I have found political scientist Deborah Yashar's Contesting Citizenship in Latin America (2005) useful for exploring indigenous political mobilizations across different models of state formation.

Using the case studies of Ecuador, Bolivia, and Peru-each of which has seen indigenous movements articulating political claims through the "new" language of ethnicity (i.e., "new" in the long timeline of indigenous politics)-Yashar examines how different state formations shape, coordinate, and channel public identities (Yashar 2005, 5-6). In particular, citizenship regimes-a complex of state institutions that define political membership, which rights people have, and how they intermediate their interests with the state-play a key role in "formally defining the intersection between national politics, political membership, and public identities" (Yashar 2005, 6). For grassroots activists, "political associational space" and transcommunity networks influence indigenous groups' success in having their grievances heard. Yashar compares how changes in Latin American citizenship regimes in the latter part of the twentieth century had consequences for indigenous movements, which emerged strong in Ecuador, regionally disparate in Bolivia, and weak in Peru. Among other findings, her cases reveal how indigenous groups' political experiences varied across communist, corporatist, and neoliberal state formations even as some patterns-such as the exploitation of indigenous land and resource rights by the state-remain sadly consistent across ideological systems.

By the time students are exposed to the Latin American cases, they have become more confident in their ability to understand the scale of the political challenges that indigenous groups face today, to see those challenges as rooted in the political development of the modern West as a project inseparable from settler colonialism, and to identify variations across political contexts. Somewhat unexpectedly, I have found that at this stage, students begin to identify many

\section{By the time students are exposed to the Latin American cases, they have become more confident in their ability to understand the scale of the political challenges that indigenous groups face today, to see those challenges as rooted in the political development of the modern West as a project inseparable from settler colonialism, and to identify variations across political contexts.}

After studying Pateman, Ford, and Bruyneel, it would be difficult for a political science student to read John Marshall's famous 1823 opinion in Johnson v. McIntosh, which justified settler sovereignty through the discovery doctrine, without a strong sense of the ideological context and on-the-ground practices that produced such a decision. Taught carefully, these historical approaches unsettle stories about early American politics that are glossed over in conventional accounts of sovereignty and law.

\section{COMPARATIVE STRUGGLES}

My third pedagogical strategy interweaves with and extends the first two. Having been exposed to the political impact of epistemology as part of Europe's imperial arsenal, and having studied throughways across course topics and are keen to test insights from one section of the class against another. For example, indigenous groups in Latin America have fought for the removal of literacy tests in their efforts toward inclusion. Students expressed interest in how such tests instantiate settler colonialism's epistemological biases. They also found ample opportunities to apply Bruyneel's third-space analysis to Latin American cases and to use Yashar's findings on citizenship regimes to think backward to the Australian and American cases we studied earlier.

In a recent iteration of the course, I noticed that throughout the term, students were generating a number of overarching topics about which they wanted to learn more. I compiled these into a list of supplementary research topics and designed a small-group 
final "teaching" assignment. Groups of three to four students conducted additional research on their chosen subject and built on the core analytical frameworks of the class to teach the topic back to their peers. This resulted in five unusually coherent presentations, including an analysis of women's roles in Canadian Idle No More activism, an analysis of how gender and sexuality intersected with race via marriage law in settler-colonialist politics, an investigation of mascot politics and their relation to shared everyday practices in the United States, and a review of the historical relationships between African Americans and the Cherokee Nation during the nineteenth century. In the future, I would add in-depth studies of individual US-Native treaties and their fate to this list.

\section{CONCLUSION}

As high school graduation rates rise for African American and Latino students, Native American graduation rates are dismal and falling in most states (Sheehy 2013). The total percentage of American Indian students enrolled in US universities has hovered around 1\% or less since 1976 (Digest of Education Statistics 2013). Native students who manage to attend college often feel isolated on campus, so retention can be difficult (Belgarde and LoRe 2003-2004). Although many Native American students may be drawn to the study of power and politics, our discipline reinforces an alienating environment when students find that their communities-whose histories and politics are inextricably interwoven with those of the dominant culture-are almost completely excluded from the major curriculum. Neither are such lacunae justified pedagogically.

Thoughtfully designed courses on indigenous peoples' politics and settler colonialism can develop transferable skills applicable to multiple topics in political science. When students are introduced to these subjects as a relevant political science content area wherein Native histories are at the center (for a change), they approach old questions with new vision. What is the function of political theory, and how has its authors' political and ideological attachments helped to justify a nation's conquering imperatives? How do epistemological frameworks produce "realities"-such as the notion of race, or civilization, or progress-deployed in political contexts to produce concrete power structures? Through which different mechanismsideas, shared everyday practices, law, institutions, cultural narratives, the state-is power operationalized? How do varieties of state formations and citizenship regimes have an impact on how minority groups leverage political claims in a rapidly changing world? How does an understanding of these mechanisms broaden mainstream political science notions of what "politics" is and where it occurs?

In a short period, the three pedagogical strategies outlined in this article can produce tremendous learning and a true reorientation toward the subjects of settler colonialism and indigenous peoples' politics. Students gain the skills to critically consider the origins and long-term legacies of political dynamics about which they typically have been trained not to think too much. Indigenous peoples typically are treated as either "people of the past"-whose histories, lives, and claims are best studied in disciplines such as history or anthropology_or as the unfortunate political losers in the tragic but unavoidable march of Western progress. Both narratives erase historical and political complexity. The scholarship reviewed in this article disrupts these assumptions by highlighting the current relevance of past practices, bringing Native peoples' perspectives into the present, and challenging students to become-if not activist allies-at least informed observers who can respect the depth, scale, and context of the political challenges that indigenous peoples are still trying to address.

\section{NOTES}

1. Settler-colonial societies are characterized by political orders based on a particular (usually European) definition of sovereignty that serves a population of immigrants who plan to stay in the land they have entered, wherein immigrant values are superimposed over those of existing indigenous communities. Settler colonialism is a global phenomenon of both past and present and, although distinct from colonialism, may be intertwined with colonial administrations (Cavanaugh and Veracini 2013, 1).

2. Page numbers referenced refer to the PDF of this forthcoming publication.

3. Author's personal communication with Kevin Bruyneel, July 24, 2013. As another indicator, Bruyneel $(2013,10)$ notes that at the annual conference of the APSA an average of only two of eight hundred panels are allocated to the topic of indigenous politics. Graduate students focusing on indigenous politics may improve this picture, but it is difficult to know how many there are currently.

4. Here, I was inspired by Lawrence and Dua $(2005,127)$, who write in the Canadian context: "Settlers find a remapping of traditional territories to early names, boundaries, and stories by Indigenous peoples to be profoundly unsettling.....It calls into question notions of settler belonging-as-whites or as peoples of color, based simply on Canadian citizenship."

5. In this sense, the study of indigenous politics can augment political science education on the subjects of slavery, women's rights, and the histories of other politically subordinated groups.

6. Another immensely useful piece I teach alongside the Smith work is Lawrence and Dua's "Decolonizing Antiracism" (2005).

\section{R E F E R E N C E S}

Belgarde, Mary Jiron, and Richard K. LoRe. 2003-2004. "The Retention/Intervention Study of Native American Undergraduates at the University of New Mexico." Journal of College Student Retention 5 (2): 175-203.

Bruyneel, Kevin. 2007. The Third Space of Sovereignty: The Postcolonial Politics of U.S.-Indigenous Relations. Minneapolis: University of Minnesota Press.

_. Forthcoming. "Political Science and the Study of Indigenous Politics." In The Oxford Handbook on Social Science and the Study of Indigenous Peoples' Politics, ed. Dale Turner and Tony Lucero. New York: Oxford University Press.

Cavanaugh, Edward, and Lorenzo Veracini. 2013. "Editors Statement." Settler Colonial Studies 3 (1): 1 .

Digest of Education Statistics, Table 237. 2013. “Total Fall Enrollment in Degree-Granting Institutions, by Level of Student, Sex, Attendance Status, and Race/Ethnicity: Selected Years 1976 through 2010." http://nces.ed.gov/ programs/digest/d11/tables/dt11_237.asp

Ford, Lisa. 2010. Settler Sovereignty: Jurisdiction and Indigenous People in America and Australia, 1788-1836. Cambridge, MA: Harvard University Press.

Fredrickson, George M. 2002. Racism: A Short History. Princeton, NJ: Princeton University Press.

Johnson and Graham's Lessee v. M'Intosh, 21 U.S. 543 (1823).

Lawrence, Bonita, and Enakshi Dua. 2005. "Decolonizing Antiracism." Social Justice $32(4): 120-43$.

McClain, Paula D., and John A. Garcia. 1993. "Expanding Disciplinary Boundaries: Black, Latino, and Racial Minority Group Politics in Political Science." In Political Science: The State of the Discipline II, ed. Ada Finifter, 247-79. Washington, DC: American Political Science Association.

Pateman, Carole, and Charles Mills. 2007. Contract and Domination. Malden, MA: Polity Press.

Peck, Danielle, and Alex Seaborne (directors). 1998. Bones of Contention. VHS cassette. Princeton, NJ: Films for the Humanities.

Sheehy, Kelsey. 2013. "Graduation Rates Dropping Among Native American Students." US News and World Report, June 6. http://bit.ly/1ftch4C.

Smith, Linda Tuhiwai. 2007. Decolonizing Methodologies: Research and Indigenous Peoples. 1oth ed. New York: Palgrave.

Smith, Rogers M. 2004. "The Puzzling Place of Race in American Political Science." PS: Political Science and Politics 37 (1): 41-5.

University of Denver Institutional Research Department. 2012. "Enrollment by Race/Ethnicity and Degree Level, All Collegiate Students, Fall 2008 to Fall 2012 (EOT).” http://www.du.edu/ir/pdf/profiles1213/enrl_race_level_f12.pdf.

Yashar, Deborah J. 2005. Contesting Citizenship in Latin America: The Rise of Indigenous Movements and the Postliberal Challenge. Cambridge: Cambridge University Press. 